\title{
BASTA! NENHUMA INCONSTITUCIONALIDADE É CONVENIENTE!
}

É inegável que a contracorrente liberal vem ganhando momento. As conquistas sociais da primeira metade do século XX vêm sendo paulatinamente negadas, sempre em razão do argumento econômico, afirmando-se a insuficiência de rendas nos Estados para implementá-las. Em algumas ocasiões, grandes manifestações populares reagem à ameaça de retirada ou encolhimento dos chamados direitos sociais. É o que acontece agora na França, com a paralisação de importantes serviços públicos visando a preservar o sistema de aposentadorias. Em outras oportunidades, a mudança legislativa é absorvida sem tantas manifestações contrárias, mas sempre em meio a intensos debates parlamentares.

Não é possível aceitar, contudo, a dissolução do direito à saúde em meio a medidas administrativas implementadas no âmbito exclusivo do Poder Judiciário, como ocorre hoje no Brasil. De fato, não há qualquer legitimidade nem mesmo uma sombra de legalidade a sustentar que o substantivo todos seja compreendido como alguns na dicção do artigo 196 da Carta Constitucional brasileira de 1988 em decorrência de ato normativo interno do Judiciário. Isso, no entanto, é o que se pretendeu com o julgamento do recurso repetitivo que foi cadastrado sob número 106 no sistema de registro dos recursos repetitivos do Superior Tribunal de Justiça.

Convém verificar do que se trata: já em 2008, foi criado pela Lei n. 11.672/2008 o procedimento para processar o recurso especial quando houver multiplicidade de recursos com fundamento em idêntica questão de direito, acrescentando o artigo 543-C ao antigo Código de Processo Civil de 1973. Pretendia-se dar celeridade à prestação jurisdicional. Tal intenção foi mantida no atual Código de Processo Civil, que entrou em vigor em 16 de março de 2016, regulando o julgamento dos recursos extraordinário e especial repetitivos no artigo 1.036 e seguintes. Nada contra o objetivo e a forma adotados, conformes aos anseios populares por uma justiça mais célere e perfeitamente obedientes às formalidades necessárias à gênese das normas jurídicas desde a Modernidade - a elaboração das normas gerais pelo Legislativo. A fixação de teses repetitivas ampliou o papel de uniformização da jurisprudência, conferindo previsibilidade e segurança jurídica aos jurisdicionados.

Por outro lado, em 1988, o Brasil afirmou que a saúde é um direito de todos. É certo que a Constituição Federal de 1988 (CF/1988) condicionou sua garantia às políticas públicas destinadas a reduzir o risco de doenças e a assegurar o acesso às ações e aos serviços destinados a promover, proteger e recuperar a saúde. Políticas públicas para todos, para garantir a saúde de todos. Isso nunca significou que todo e qualquer produto, bem ou inovação pretensamente atuante no campo da redução dos riscos de 
doenças ou na promoção, proteção ou recuperação da saúde deva ser assegurado. Não. Sempre se desejou que as políticas públicas fossem competentes para identificar os melhores meios e produtos seguros e eficazes, tornando-os imediatamente disponíveis para todos aqueles que deles necessitarem. Supõem-se, então, a necessidade de um sistema de saúde complexo, capaz de responder tecnicamente a tais exigências.

Mas, no Estado Democrático de Direito, não basta a competência técnica do sistema; é preciso que ele responda ao mandamento da vontade popular expressa inclusive diretamente, e não mais apenas por meio de seus representantes eleitos. Particularmente no caso brasileiro, o sistema de saúde deve ser organizado, por exigência constitucional, com a participação da comunidade. Assim, cada uma das decisões tomadas visando a identificar os melhores meios e produtos seguros e eficazes ou a torná-los imediatamente disponíveis para todos aqueles que deles necessitarem deve passar pelo crivo da vontade popular diretamente manifestada nas instâncias previstas, a fim de abrigar tal manifestação na estrutura do sistema de saúde.

Nenhum obstáculo, portanto, a eventuais limitações na oferta de ações, serviços, bens e produtos de interesse para a saúde de todos. Basta que qualquer uma dessas limitações encontre justificativas técnicas e seja apoiada pela comunidade. O que não pode acontecer, porque absolutamente inconstitucional, é a limitação do direito à saúde a alguns. A saúde é direito de todos. Nada mais claro. Qualquer interpretação que exclua uma só pessoa da garantia desse direito é absurda e deve ser denunciada. Todos significa todos.

É escandaloso que tenha sido um órgão da cúpula do Poder Judiciário a se aventurar por caminho tão afastado do direito e da Constituição. Com efeito, foi em uma decisão da Primeira Seção do Superior Tribunal de Justiça que se fixou o requisito da comprovação da incapacidade financeira do paciente de arcar com o custo do medicamento prescrito para que o Poder Judiciário determine o fornecimento de remédios fora da lista do Sistema Único de Saúde (SUS). Ora, "todos" não significa apenas aqueles que não tenham condições financeiras. A saúde é direito de todos, sem distinção de qualquer natureza, inclusive de condição financeira.

É por todos os títulos lamentável que tenha sido um órgão do próprio Poder Judiciário a infringir tão claramente dispositivos constitucionais expressos com tal limpidez: "Todos são iguais perante a lei, sem distinção de qualquer natureza" (CR art. 5); "A saúde é direito de todos" (art. 196, CF/1988). Basta! nenhuma inconstitucionalidade é conveniente!

Sueli Gandolfi Dallari

Editora científica 